\title{
HOW DOES OUR BRAIN AFFECT OUR POCKET?
}

\author{
DOI: 10.17261/Pressacademia.2021.1534 \\ PAP- V.14-2021(56)-p.182-183
}

\section{Sezen Gungor}

Tekirdag Namik Kemal University, Corlu Vocational School, Department of Business, Tekirdag, Turkey. sezengungor@nku.edu.tr, ORCID: 0000-0001-8388-6350

\author{
To cite this document \\ Gungor, S., (2021). How does our brain affect our pocket? PressAcademia Procedia (PAP), 14, 182-183.

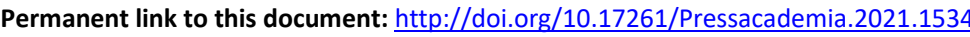 \\ Copyright: Published by PressAcademia and limited licensed re-use rights only.
}

\begin{abstract}
Purpose- The science of neurology, in which behavioral finance works closely, questioning the theories of traditional finance and the assumptions on which these theories are based, has enabled groundbreaking studies in the finance literature. However, the understanding of "I only know my own work well", which is the main problem in interdisciplinary and multidisciplinary studies, often causes difficulties in the interpretation of empirical studies. The main purpose of this study is to introduce neurofinance researchers, who dominate my finance literature but are not very familiar with neurology concepts, to introduce the basic neurofinance concepts that should be known, and to guide scientists who want to work in the field of neurofinance.

Methodology- Literature review method was used in the study. The concepts that show the brain-financial behavior relations, which are revealed as a result of studies in the field of neurofinance, are examined.

Conclusion- As a result of the study, some brain regions that were associated with financial behavior and some brain secretions, especially dopamine and serotonin, were listed.
\end{abstract}

Keywords: Neurofinance, behavioral finance, decision making

JEL Codes: D87, G40, G41

\section{BEYNIMIZ CEBIMIZI NASIL ETKILER?}

\section{ÖZET}

Amaç- Geleneksel finansın kuramlarını ve bu kuramların dayandığı varsayımları sorgulayan davranışsal finansın yakın ilişkide çalıştı̆ı nöroloji bilimi, finans literatüründe çı̆̆ır açan çalışmalara olanak vermiştir. Ancak disiplinlerarası ve çok disiplinli çalışmalardaki temel sorun olan "ben sadece kendi işimi iyi bilirim" anlayışı, çoğu zaman yapılan ampirik çalışmaların yorumlanmasında sıkıntılar yaşanmasına neden olmaktadır. Bu çalışmanın temel amacı, finans literatürüme hakim olan ancak nöroloji kavramlarına pek aşina olmayan araştırmacıları, nörofinans ile tanışımak, bilinmesi gereken temel nörofinans kavramlarını tanıtmak ve nörofinans alanında çalışmalar yapmak isteyen bilim insanlarına yol göstermektir.

Yöntem- Çalışmada literatür taraması yöntemi kullanılmıştır. Nörofinans alanında yapılan çalışmalar sonucunda ortaya konan beyin-finansal davranış ilişkilerini gösteren kavramlar irdelenmiştir.

Bulgular- Çalışma sonucunda finansal davranış ile ilişkisi ortaya konan bazı beyin bölgeleri ile dopamin ve serotonin başta olmak üzere bazı beyin salgıları sıralanmıştır.

Sonuç- Çalışmanın umulan sonucu, nörofinans alanında yapılacak çalışmalara yol göstermektir. Dopamin, serotonin, amigdala, prefrontal korteks ve diğe nörolojik kavramların finans uzmanları tarafından bilinmesinin, gelecekte yapılması planlanan nörofinans çalışmalarının yorumlanması açısından önemli olduğu düşünülmektedir.

Anahtar Kelimeler: Nörofinans, davranışsal finans, karar verme

JEL Kodları: D87, G40, G41

\section{KAYNAKÇA}

Anisa, N., \& Riyanto, S. (2020). Effect of Business Performance and Working Culture on Consumer Buying Decisions During Pandemic Covid19. International Journal of Innovative Science and Research Technology, 5(6), 620-624.

Archuleta, K. L., Dale, A., \& Spann, S. M. (2013). College students and financial distress: Exploring debt, financial satisfaction, and financial anxiety. Journal of Financial Counseling and Planning, 24(2), 50. 
Atalan, A. (2020). Is the lockdown important to prevent the COVID-19 pandemic? Effects on psychology, environment and economyperspective. Annals of medicine and surgery, 56, 38-42.

Barrera, M., Caples, H., \& Tein, J. Y. (2001). The psychological sense of economic hardship: Measurement models, validity, and cross-ethnic equivalence for urban families. American Journal of Community Psychology, 29(3), 493-517.

Bick, A., Blandin, A., \& Mertens, K. (2020). Work from home after the COVID-19 Outbreak.

Conger, R. D., Conger, K. J., Elder, G. H., Lorenz, F. O., Simons, R. L., \& Whitbeck, L. B. (1993). Family economic stress and adjustment of early adolescent girls. Developmental Psychology, 29(2), 206-217.

Conger, R. D., Ge, X., Elder, G. H., Lorenz, F. O., \& Simons, R. L. (1994). Economic stress, coercive family process, and developmental problems of adolescents. Child development, 65(2), 541-561.

Drentea, P., \& Reynolds, J. R. (2012). Neither a borrower nor a lender be: The relative importance of debt and SES for mental health among older adults. Journal of aging and health, 24(4), 673-695.

Falato, A., Goldstein, I., \& Hortaçsu, A. (2021). Financial fragility in the COVID-19 crisis: The case of investment funds in corporate bond markets. Journal of Monetary Economics, 177-182.

Fiksenbaum, L., Marjanovic, Z., \& Greenglass, E. (2017). Financial threat and individuals' willingness to change financial behavior. Review of Behavioral Finance, 9(2), 128-147.

Fiksenbaum, L., Marjanovic, Z., \& Greenglass, E. (2017). Financial threat and individuals' willingness to change financial behavior. Review of Behavioral Finance, 9(2), 128-147.

Goodell, J. W. (2020). COVID-19 and finance: Agendas for future research. Finance Research Letters, 35, 101512.

Greenglass, Esther, Zdravko Marjanovic and Lisa Fiksenbaum, 2013. "Impact of the recession and its aftermath on individual health and wellbeing." In Clary L. Cooper and Alexander S. G. Antoniou (Eds.), The Psychology of the Recession in the Workplace, 42-58. Cheltenham, UK: Edward Elgar.

Gupta, M., Abdelmaksoud, A., Jafferany, M., Lotti, T., Sadoughifar, R., \& Goldust, M. (2020). COVID-19 and economy. Dermatologic therapy.

Ishtiaq, M., Tufail, M. S., Shahzad, K., \& Naseer, M. A. (2019). Impact of Financial Threat on Individual's Willingness to Change Financial Behavior. Dialogue, 6462(14), 2-15.

Janssens, W., Pradhan, M., de Groot, R., Sidze, E., Donfouet, H. P. P., \& Abajobir, A. (2021). The short-term economic effects of COVID-19 on low-income households in rural Kenya: An analysis using weekly financial household data. World Development, 138, 105280.

Lemoine, J., Darriet, E., Kmiec, R. and Roland-Lévy, C. (2017). Financial threat during the economic crisis: Its influence on the social representation and the willingness to act. International Review of Social Psychology 29(1), 113-126.

Marjanovic vd.. (2015). Evaluation of the Financial Threat Scale (FTS) in four European, nonstudent samples. Journal of Behavioral and Experimental, 72-80.

Marjanovic, Zdravko, Esther R. Greenglass, Lisa Fiksenbaum and Chris M. Bell, 2013. "Psychometric evaluation of the Financial Threat Scale (FTS) in the context of the great recession." Journal of Economic Psychology, 36, 1-10.

Metselaar, E. E. (1997). Assessing the willingness to change: Construction and validation of the DINAMO.

Microbe, T. L. (2021). COVID-19 vaccines: the pandemic will not end overnight. The Lancet. Microbe, 2(1), e1.

Moore, K. A. (2012). Self-Efficacy as a psychological resource in difficult economic times. In Stress and Anxiety: Application to Economic Hardship, Occupational Demands, and Developmental Challenges, 29-37.

Perelman, D. (2020). In the Covid-19 Economy, You Can Have a Kid or a Job. You Can't Have Both.

Rawson, T., Brewer, T., Veltcheva, D., Huntingford, C., \& Bonsall, M. B. (2020). How and when to end the COVID-19 lockdown: an optimization approach. Frontiers in Public Health, 8, 262

Scacchi, A., Catozzi, D., Boietti, E., Bert, F., \& Siliquini, R. (2021). COVID-19 lockdown and self-perceived changes of food choice, waste, impulse buying and their determinants in Italy: QuarantEat, a cross-sectional study. Foods, 10(2), 306.

Sheth, J. (2020). Impact of Covid-19 on consumer behavior: Will the old habits return or die?. Journal of Business Research, 117, $280-283$. 